\title{
Cost-effectiveness of pneumococcal conjugate vaccination in Latin America and the Caribbean: a regional analysis
}

\author{
Anushua Sinha, ${ }^{1,2}$ Dagna Constenla, ${ }^{3}$ Juan Esteban Valencia, ${ }^{4}$ \\ Rosalyn O'Loughlin, ${ }^{5}$ Elizabeth Gomez, ${ }^{6}$ Fernando de la Hoz, ${ }^{7}$ \\ Maria Teresa Valenzuela, ${ }^{8}$ and Ciro A. de Quadros $^{9}$
}

Suggested citation

Sinha A, Constenla D, Valencia JE, O’Loughlin R, Gomez E, de la Hoz F, Valenzuela MT, de Quadros CA. Cost-effectiveness of pneumococcal conjugate vaccination in Latin America and the Caribbean: a regional analysis. Rev Panam Salud Publica. 2008;24(5):304-13.

ABSTRACT

Key words
Objective. In Latin America and the Caribbean, routine vaccination of infants against Streptococcus pneumoniae would need substantial investment by governments and donor organizations. Policymakers need information about the projected health benefits, costs, and cost-effectiveness of vaccination when considering these investments. Our aim was to incorporate vaccine, demographic, epidemiologic, and cost data into an economic analysis of pneumococcal vaccination of infants in Latin America and the Caribbean.

Methods. We previously used a structured literature review to develop regional estimates of the incidence of disease. Cost data were collected from physician interviews and public fee schedules. We then constructed a decision analytic model to compare pneumococcal conjugate vaccination of infants with no vaccination across this region, examining only vaccine's direct effects on children.

Results. Pneumococcal vaccination at the rate of diphtheria-tetanus-pertussis vaccine coverage was projected to prevent 9500 deaths per year in children aged 0 to 5 years in the region, or approximately one life saved per 1100 infants vaccinated. These saved lives as well as averted cases of deafness, motor deficit, and seizure result in 321000 disability-adjusted life years (DALYs) being averted annually. At vaccine prices between US\$5 and US\$53 per dose, the cost per DALY averted from a societal perspective would range from US\$154 to US\$5 252. Conclusion. Pneumococcal conjugate vaccine was highly cost-effective up to $\$ 40$ per dose. Introduction of pneumococcal vaccine in the Latin American and Caribbean region is projected to reduce childhood mortality and to be highly cost-effective across a range of possible costs.

Streptococcus pneumoniae, pneumococcal vaccines, costs and cost analysis, decision trees, otitis media, pneumonia, sepsis, meningitis, Latin America and the Caribbean.
1 University of Medicine and Dentistry of New Jersey, New Jersey Medical School, Newark, New Jersey, United States of America. Send correspondence and reprint requests to: Anushua Sinha, University of Medicine and Dentistry of New Jersey, New Jersey Medical School, 185 South Orange Avenue, MSB F506, Newark, New Jersey 07090, United States of America; telephone: +1-973-9726538; fax: +1-973-972-7625; e-mail: sinhaan1@ umdnj.edu.
2 University of Medicine and Dentistry of New Jersey, School of Public Health, Newark, New Jersey, United States of America.

3 Independent consultant, Fort Collins, Colorado, United States of America.

4 Universidad CES, Medellín, Colombia.

5 Respiratory Diseases Branch, National Center for Immunizations and Respiratory Diseases, Centers for Disease Control and Prevention, Atlanta, Georgia, United States of America.
6 Dirección General de Epidemiología, Secretaria de Estado de Salud Publica, Santo Domingo, Republica Dominicana.

Universidad Nacional de Colombia, Facultad de Medicina, Bogota, Colombia.

8 Departamento de Salud Pública y Epidemiología Universidad de los Andes, Facultad de Medicina, Santiago, Chile.

9 Sabin Vaccine Institute, Washington, D.C., United States of America. 
Streptococcus pneumoniae, or pneumococcus, is an important cause of bacterial pneumonia, meningitis, bacteremia, sepsis, and acute otitis media, resulting in morbidity, mortality, and costs to the health care system. The World Health Organization (WHO) estimates that 1.6 million deaths occur annually due to pneumococcus, of which approximately 800000 are among children less than 5 years of age (1). An effective seven-valent pneumococcal conjugate vaccine (PCV) has been licensed in the United States since 2000 and has been shown to reduce the likelihood of pneumococcal disease in young children and to reduce transmission from young children to adults (2). Higher valency conjugate products are in development (3).

However, PCV has yet to be introduced in many low- and middleincome countries. In Latin America, several countries including Panama, Costa Rica, Guyana, Honduras, and Nicaragua are planning to introduce the vaccine into their routine immunization programs. Other countries-including Mexico, Brazil, Chile, and Colombia-have targeted immunization programs in place. However, economic analyses from the region to support the introduction of PCV are sparse and primarily consist of cost-of-illness studies (4-12). Experience with other recent vaccines suggests that, without coordinated effort, a PCV is unlikely to reach children in Latin American and Caribbean countries without substantial delays $(13,14)$.

The goal of this regional analysis was to provide decision makers with estimates of the burden and costs of pneumococcal disease in Latin America and the Caribbean as well as the cost-effectiveness of the purchase and provision of seven-valent PCV from the societal perspective. It was conducted as a companion analysis to a regional, systematic review of the economic and epidemiologic pneumococcal literature. The methods and results of the systematic literature review are described in detail elsewhere (15).

\section{MATERIALS AND METHODS}

\section{Overview}

We constructed a decision analytic model using standard methods $(16,17)$ to assess the child lives saved, disability-adjusted life years (DALYs) averted, costs, and cost-effectiveness of pneumococcal conjugate vaccination of infants in the Latin American and Caribbean region. The countries covered by this analysis are listed in Table 1. We evaluated these outcomes at a regional level, using model inputs developed to represent the Latin American and Caribbean region rather than individual countries. Latin American countries have a pooled birth cohort of 11700500 annually. Vaccinerelated costs, disease costs, and incident cases of disease were estimated for members of the birth cohort between birth and age 5 years. Input was sought from regional experts via teleconference and face-to-face meetings during model development and model revision. A discount rate of 3\% was applied to both health benefits and costs.

\section{Model structure}

The decision tree (Figure 1) included two strategies: (1) vaccine introduction, in which a seven-valent PCV was introduced across Latin America and the
Caribbean, and (2) no vaccine introduction. In the vaccine introduction strategy, each child born had a probability of developing acute otitis media due to any cause, clinical pneumonia due to any cause, chest $\mathrm{x}$-ray-confirmed pneumonia due to any cause, pneumococcal sepsis, or pneumococcal meningitis. We chose to analyze acute otitis media and pneumonia due to any cause, rather than pneumococcal otitis or pneumococcal pneumonia, to take advantage of clinical trial data, which present vaccine efficacies against all-cause disease for these syndromes, rather than pneumococcal disease (18-20).

Probabilities of disease depended on whether the child received the vaccine and the vaccine's efficacy against disease. Disease resulted in the accrual of DALYs and costs. These DALYs and costs varied depending on the type of disease experienced and whether the child survived, died, or had permanent disability. Preventing disease through vaccination averted both DALYs and disease-related costs. The vaccination program resulted in costs related to purchase of vaccine and to program administration.

The set of assumptions used to perform the primary analysis is termed the base case analysis (Table 2) (21-27). Our base case was conservative in that it did not account for herd protection-a vaccine's indirect protective effects on nonvaccinated populations

TABLE 1. Countries in the Latin American and Caribbean region

\begin{tabular}{|c|c|}
\hline Region & Countries \\
\hline Central American isthmus & $\begin{array}{l}\text { Belize, Costa Rica, El Salvador, Guatemala, Honduras, Nicaragua, } \\
\text { Panama }\end{array}$ \\
\hline Andean area & Bolivia, Colombia, Ecuador, Peru, Venezuela \\
\hline Southern cone & $\begin{array}{l}\text { Argentina, Chile, Paraguay, Uruguay, Suriname, Trinidad and Tobago, } \\
\text { Turks and Caicos Islands, Virgin Islands (United Kingdom), Virgin } \\
\text { Islands (United States) }\end{array}$ \\
\hline Non-Latin Caribbean & $\begin{array}{l}\text { Anguilla, Antigua and Barbuda, Aruba, The Bahamas, Barbados, } \\
\text { Cayman Islands, Dominica, Grenada, Guyana, Jamaica, Montserrat, } \\
\text { Netherlands Antilles, Saint Kitts and Nevis, Saint Lucia, Saint Vincent } \\
\text { and the Grenadines }\end{array}$ \\
\hline Latin Caribbean & $\begin{array}{l}\text { Cuba, Dominican Republic, French Guiana, Guadeloupe, Haiti, } \\
\text { Martinique, Puerto Rico }\end{array}$ \\
\hline Other & Brazil, Mexico \\
\hline
\end{tabular}


FIGURE 1. Decision tree depicting the two policy options (regional vaccine introduction versus no vaccine) and subsequent events that may be experienced by each child

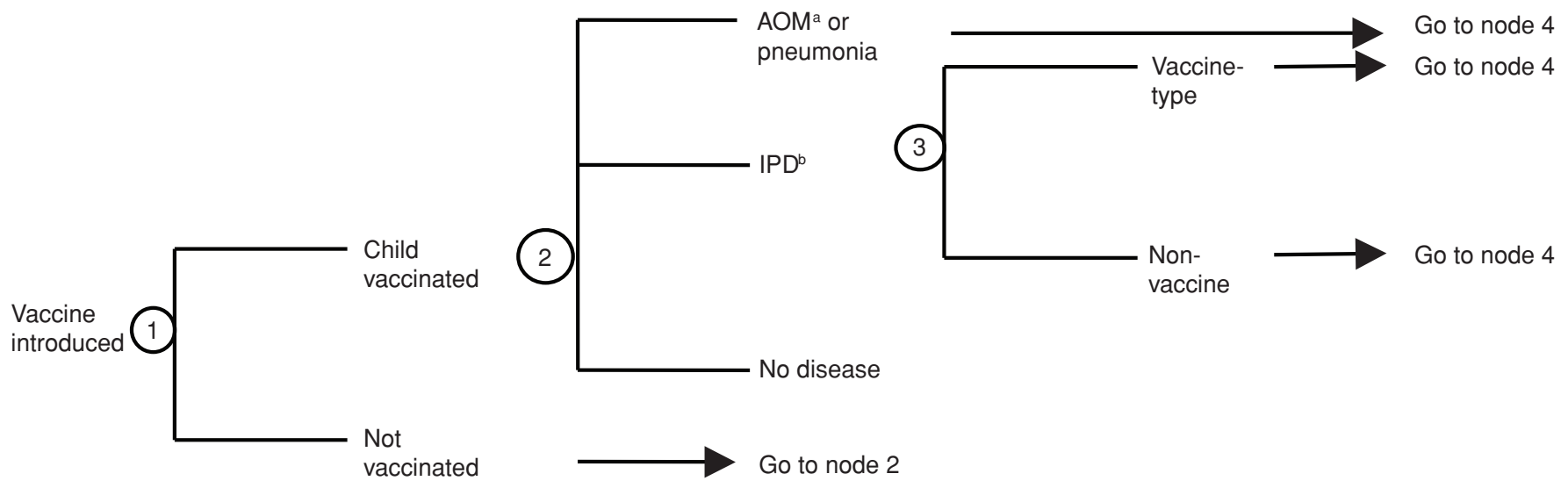

No vaccine $\longrightarrow$ Go to node 2

${ }^{\text {a }} \mathrm{AOM}=$ acute otitis media.

b $I P D=$ invasive pneumococcal disease.

(e.g., nonvaccinated children, adolescents, and adults). In the United States, large herd protection effects have been observed with consequent large effects on the cost-effectiveness of vaccine in other populations (28-29).

\section{Probabilities}

PCV was assumed to be administered in a three-dose schedule, according to the schedule for vaccines containing diphtheria-tetanus-pertussis (DTP) in most member states of the Pan American Health Organization (PAHO) $(2,4$, and 6 months of age). We assumed vaccine efficacy for a three-dose schedule would be the same as for the four-dose schedule used in some clinical trials (30). We chose to model a three-dose schedule because of the efficacy of such schedules in other clinical trials $(31,32)$ and because three-dose schedules have been proposed for Global Alliance for Vaccines and Immunizations-eligible countries (33). It was assumed that pneumococcal vaccination rates would be equal to the regional average proportion of children reported to receive three doses of DTP vaccine in 2005 (DTP3 rate) (21).

Estimates of seven-valent PCV efficacy were available from several large, randomized controlled trials. No trial results were available from a Latin American or Caribbean setting. Our analyses were based on the results of the seven-valent PCV trial conducted in Northern California Kaiser Permanente (18-20). The vaccine efficacy estimate for chest x-ray-confirmed pneumonia was based on a later reanalysis of the original trial's results (27). While the study setting was in the United States, a high-income country, it was also in the region of the Americas and perhaps most closely approximated the setting of other American countries.

We assumed that vaccine would prevent cases of disease and deaths between ages 0 and 5 years only and that vaccine efficacy would be constant for these young children. To extrapolate trial results to Latin America and the Caribbean, we adjusted vaccine efficacies by the ratio of the regional estimate for vaccine serotype coverage and the trial vaccine serotype coverage.

Regional estimates of serotype distribution, annual incidences of disease, and case fatality rates were based on a systematic review of the published and unpublished literature. Methods pertaining to the literature review and 
TABLE 2. Model assumptions for Latin American and Caribbean regional analysis

\begin{tabular}{|c|c|c|c|c|}
\hline \multirow[b]{2}{*}{ Model input } & \multirow[b]{2}{*}{$\begin{array}{l}\text { Base case } \\
\text { estimate }\end{array}$} & \multicolumn{2}{|c|}{ Plausible range } & \multirow[b]{2}{*}{ Source } \\
\hline & & $\begin{array}{l}\text { Lower } \\
\text { limit }\end{array}$ & $\begin{array}{l}\text { Upper } \\
\text { limit }\end{array}$ & \\
\hline Birth cohort & 11700500 & $\ldots$ & $\ldots$ & PAHO (21) \\
\hline Life expectancya & 72.3 & $\ldots$ & $\ldots$ & WHO (22) \\
\hline Discount rate & $3 \%$ & $3 \%$ & $7 \%$ & Gold et al. (16) \\
\hline Probability of clinical pneumonia & 0.0911 & 0.1394 & 0.1485 & Valenzuela et al. (24) \\
\hline Probability of chest $x$-ray-confirmed pneumonia & 0.0572 & 0.0435 & 0.0714 & Valenzuela et al. (24) \\
\hline Probability of pneumococcal sepsis & 0.0001 & 0.00008 & 0.00013 & Valenzuela et al. (24) \\
\hline Probability of pneumococcal meningitis & 0.0003 & 0.00022 & 0.00058 & Valenzuela et al. (24) \\
\hline \multicolumn{5}{|l|}{ Case fatality ratios } \\
\hline Clinical pneumonia & $3 \%$ & $1.9 \%$ & $5.5 \%$ & Valenzuela et al. (24) \\
\hline Chest $x$-ray-confirmed pneumonia & $5.4 \%$ & $5.1 \%$ & $5.8 \%$ & Valenzuela et al. (24) \\
\hline Probability that clinical pneumonia is hospitalized ${ }^{a}$ & 0.08 & $\ldots$ & $\ldots$ & Rudan et al. (25) \\
\hline $\begin{array}{l}\text { Probability that chest } x \text {-ray-confirmed pneumonia is } \\
\text { hospitalized }\end{array}$ & 0.64 & $\cdots$ & . & Rudan et al. (25) \\
\hline \multicolumn{5}{|l|}{ Disability-related inputs } \\
\hline Probability of deafness due to pneumococcal meningitis & 0.13 & $\ldots$ & . & Constenla (26) \\
\hline Probability of seizure disorder due to pneumococcal meningitis & 0.17 & $\ldots$ & $\ldots$ & Constenla (26) \\
\hline Probability of motor disorder due to pneumococcal meningitis & 0.16 & $\ldots$ & $\cdots$ & Constenla (26) \\
\hline \multicolumn{5}{|l|}{ Vaccine-related inputs } \\
\hline Proportion vaccinated (DTP3 rate) & $92 \%$ & $92 \%$ & $100 \%$ & PAHO (27) \\
\hline \multicolumn{5}{|l|}{ Vaccine efficacy } \\
\hline Against acute otitis media & $7 \%$ & $4 \%$ & $10 \%$ & Black et al. (19) \\
\hline Against clinical pneumoniab & $3 \%$ & $-4 \%$ & $9 \%$ & Black et al. (18) \\
\hline Acute otitis media & $\$ 101$ & $\$ 78$ & $\$ 234$ & Physician and parent surveys ${ }^{c}$ \\
\hline Hospitalized clinical or chest $x$-ray-confirmed pneumonia & $\$ 1017$ & $\$ 571$ & $\$ 2174$ & Physician and parent surveys ${ }^{c}$ \\
\hline Outpatient clinical or chest $\mathrm{x}$-ray-confirmed pneumonia & $\$ 117$ & $\$ 80$ & $\$ 236$ & Physician and parent surveys ${ }^{c}$ \\
\hline Hospitalized sepsis & $\$ 1344$ & $\$ 914$ & $\$ 1543$ & Physician and parent surveys ${ }^{c}$ \\
\hline Hospitalized meningitis & $\$ 1843$ & $\$ 680$ & $\$ 2802$ & Physician and parent surveys ${ }^{\mathrm{C}}$ \\
\hline
\end{tabular}

${ }^{a}$ Weighted average, using country-level birth cohort estimates as the weights.

${ }^{\mathrm{b}}$ Adjusted for regional differences in pneumococcal serotype distribution by multiplying published vaccine efficacy by $(60 \% / 80 \%)$.

c See text.

aggregation of data into summary measures of disease incidence and burden have been described elsewhere (24). Age-specific, annual disease incidences were converted into cumulative incidences (probabilities) by standard Kaplan-Meier methods (34). Age distribution of disease was based on results from a survey of 24 health care providers in three Latin American countries (Brazil, Chile, and Uruguay). The details of survey methods and results are described elsewhere (35). The proportion of cases of clinical pneumonia that are hospitalized was based on regional estimates of the proportion of acute lower respiratory infections in children that are severe (25).

\section{Costs}

All costs are expressed in 2005 U.S. dollars. The costs of vaccination include the cost of administration, the price of each dose, the number of doses given (based on coverage level), and expected losses from waste. The price at which vaccine will be made 
available to low- and middle-income countries in Latin America and the Caribbean is unknown. Our base case used \$53 per vaccine dose, the price at which a dose of vaccine was purchased by PAHO's Revolving Fund for Vaccine Procurement in 2006. This dose cost was varied widely in sensitivity analysis, given the possibility that cost will decline as additional manufacturers enter the market and, potentially, as increasing numbers of countries introducing the vaccine result in increasing volume purchased through the Revolving Fund. Incremental vaccine administration costs (cold chain, transport, personnel, injection supplies, training, other) were based on an assumption of \$1 per dose; a $10 \%$ wastage rate was assumed.

Direct medical costs related to pneumococcal disease included hospital days, medical personnel time, outpatient visits, diagnostic tests, and medications. These costs were derived from detailed interviews conducted regarding resource utilization with 57 physicians in 10 Latin American and Caribbean countries: Argentina, Brazil, Chile, Colombia, Dominican Republic, Honduras, Mexico, Panama, Uruguay, and Venezuela. These interview data on resource utilization were combined with unit cost data from the finance departments of local hospitals, national administrative data, and national formulary data to derive the total direct medical cost per case of disease. Further methods and the interview survey tool are described elsewhere (15). Cost estimates were from the public sector.

Direct nonmedical costs included transportation to health care facilities and parent or caregiver time spent caring for a sick child. These costs were calculated based on interviews with 60 parents of sick children regarding money spent to transport a child or themselves to the health facility, time lost from paid work due to their child's illness, and days off work and income lost due to pneumococcal disease. The average cost of caregiver time was estimated by multiplying the mean hours lost by the mean female hourly wage for each of the countries. Further details of the cost analysis methods and results are described elsewhere (15).

\section{Health outcomes}

The base case analysis considered cases of disease, hospitalizations, and deaths averted by vaccination. Cases averted and deaths averted were converted into years of life lost and years of life lived with disability and then were aggregated into DALYs, a standard measure of disease burden used by WHO and the World Bank (36). We used standard methods and assumptions-including age-weighting, discounting, and disability weights-in estimating DALYs $(36,37)$. The DALY parameters used were a discount rate $(r)$ of 0.03 , an age-weighting factor $(K)$ of 1 , and an age-weighting parameter $(\beta)$ of 0.04 . The disability weights $(D)$ for chronic disability were from a standard reference (36) and were for deafness (0.175), seizure (0.041), and motor deficit (0.334). Disability weights for acute illness were also taken from this standard reference and were for otitis media (0.023), bacteremia (0.152), pneumonia (0.280), and meningitis (0.616) (36). DALYs averted were based on a regional average life expectancy $(L)$ at age 1 year from standard life tables (22).

\section{Analyses}

The base case analysis was performed from a societal perspective, including all direct medical and nonmedical costs borne by governments and families. In a secondary analysis, we considered the health care system perspective, in which only the costs borne by medical facilities, providers of health care, and other facilities and providers of vaccine-related services are considered. We estimated incremental cost-effectiveness ratios (CERs) for each country based on the following formula:
$\mathrm{CER}=$ (vaccine-related costs - costs of disease averted)/(DALYs averted)

The CER numerator and denominator were calculated by multiplying probabilities in the decision tree by values for costs and DALYs, using standard decision analytic methods $(16,17)$. All future costs and health benefits were discounted at an annual rate of $3 \%$, as recommended by the U.S. Panel of Cost-Effectiveness in Health and Medicine (16).

As standards of comparison, we used WHO thresholds of cost-effective interventions defined as CERs less than three times per capita gross domestic product (GDP) and highly costeffective interventions defined as CERs below one time per capita GDP (38). To test the robustness of model results, we varied each assumption over a plausible range in one-way and selected two-way sensitivity analyses.

Because decision makers will be interested in the proportion and $a b$ solute number of cases due to pneumococcus, we used the model's estimated numbers of averted cases of all-cause acute otitis media, clinical pneumonia, and chest $x$-ray-confirmed pneumonia and performed the following calculation to estimate numbers of pneumococcus-specific cases for each disease:

Number of pneumococcal cases of syndrome $=$ (number of averted cases of all-cause syndrome)/ ((\% serotypes covered by vaccine) $\times(\%$ vaccine coverage $) \times($ vaccine efficacy against vaccine-type invasive pneumococcal disease))

Analyses were done with Microsoft Excel (Microsoft Corp., Redmond, Washington, USA).

\section{RESULTS}

\section{Health outcomes}

In the Latin American and Caribbean region, we projected that, without pneumococcal vaccination, 
10530000 cases of otitis media due to any cause, 1065000 cases of clinical pneumonia due to any cause, 669000 cases of chest x-ray-confirmed pneumonia due to any cause, 3900 cases of pneumococcal meningitis, and 1200 cases of pneumococcal sepsis would occur annually in children aged 0 to 5 years (Table 3 ). Of the otitis media and pneumonia cases, 1261000 cases of otitis media and 327000 cases of clinical and chest $x$-ray-confirmed pneumonia were estimated to be due to pneumococcus. Pneumococcal cases were associated with 182000 hospitalizations (16 per 1000 children) and 1412000 outpatient visits (121 per 1000 children) annually.

PCV was projected to prevent 857000 cases of pneumococcal disease annually, including 9500 deaths, and averted 321000 DALYs annually if delivered at coverage rates similar to those for DTP3. Overall, PCV saved 0.9 life per 1000 children vaccinated (1 per 1 100) and averted 60 cases of disease per 1000 children vaccinated.

In absolute numbers, the largest numbers of cases prevented would result from the vaccine's effects on acute otitis media. Although generally a nonfatal disease of limited duration, acute otitis media was associated with a large number of health care visits (1 261000 ) and direct medical costs (\$103 793 000). Pneumonia was associated with a large number of hospitalizations (177 000) as well as direct medical costs (\$166 206000$)$.

\section{Costs}

If current DTP3 coverage rates were achieved for PCV across the region, 33.4 million doses of vaccine would be needed annually. Total vaccine program costs would be approximately \$1 802 million per year, including $\$ 1769$ million for vaccine purchase at $\$ 53$ dollars per dose. In our base case analysis, vaccination would avert $\$ 152$ million in disease costs in direct medical and nonmedical costs annually. The undiscounted net costs (vaccine program costs minus averted

TABLE 3. Projected health outcomes of pneumococcal conjugate vaccination in Latin America and the Caribbean

\begin{tabular}{lrrrr}
\hline & \multicolumn{1}{c}{$\begin{array}{c}\text { No } \\
\text { vaccine }\end{array}$} & $\begin{array}{c}\text { With } \\
\text { vaccination }\end{array}$ & $\begin{array}{r}\text { Events } \\
\text { averted }\end{array}$ & $\%$ averted \\
\hline Acute otitis media $^{a}$ & 10530000 & 9852000 & 678000 & 6 \\
Clinical pneumonia $^{a}$ & 1065000 & 1034000 & 32000 & 3 \\
Chest x-ray-confirmed pneumonia $^{a}$ & 669000 & 525000 & 144000 & 22 \\
Pneumococcal sepsis $^{\text {Pneumococcal meningitis }}$ & 1200 & 570 & 660 & 54 \\
Deaths $^{b}$ & 3900 & 1800 & 2100 & 54 \\
DALYs & 235000 & 60000 & 9500 & 14 \\
\hline
\end{tabular}

a Due to any cause.

${ }^{b}$ Due to clinical pneumonia, chest x-ray-confirmed pneumonia, pneumococcal sepsis, or pneumococcal meningitis.

TABLE 4. Projected cost-effectiveness of pneumococcal conjugate vaccination in Latin America and the Caribbean

\begin{tabular}{|c|c|c|c|c|c|}
\hline \multirow[b]{2}{*}{ Dose cost } & \multirow{2}{*}{$\begin{array}{c}\text { Total } \\
\text { vaccine-related } \\
\text { costs } \\
\text { (million) })^{\mathrm{a}}\end{array}$} & \multirow{2}{*}{$\begin{array}{l}\text { Net costs, } \\
\text { societal } \\
\text { perspective } \\
\text { (million) }^{a, b}\end{array}$} & \multicolumn{2}{|c|}{$\$$ per DALY averted } & \multirow[b]{2}{*}{$\begin{array}{c}\text { \$ per life saved, } \\
\text { societal } \\
\text { perspective }^{c}\end{array}$} \\
\hline & & & $\begin{array}{c}\text { Healthcare } \\
\text { perspective }^{\mathrm{C}}\end{array}$ & $\begin{array}{c}\text { Societal } \\
\text { perspective }^{c}\end{array}$ & \\
\hline$\$ 53$ & 1802 & 1650 & 5735 & 5252 & 178364 \\
\hline$\$ 40$ & 1368 & 1216 & 4354 & 3871 & 131470 \\
\hline$\$ 30$ & 1034 & 882 & 3292 & 2809 & 95398 \\
\hline$\$ 20$ & 701 & 549 & 2230 & 1747 & 59325 \\
\hline$\$ 10$ & 367 & 215 & 1168 & 685 & 23253 \\
\hline$\$ 5$ & 200 & 48 & 637 & 154 & 5216 \\
\hline
\end{tabular}

a Undiscounted costs.

${ }^{b}$ Net costs = Total vaccine-related costs minus averted disease costs.

c Using discounted costs and health benefits.

disease costs) were \$1 650 million annually. These net costs decreased as vaccine dose cost decreased; at \$5 per dose, the net costs from the societal perspective were $\$ 48$ million (Table 4 ).

\section{Cost-effectiveness}

From a societal perspective, pneumococcal vaccination will cost between \$154 and \$5 252 per DALY averted across the Latin American and Caribbean region, as the cost per dose of vaccine ranges from $\$ 5$ to $\$ 53$ (Table 4). Across all dose costs less than or equal to $\$ 40$, pneumococcal vaccination was projected to be costeffective, using WHO benchmarks and a weighted average per capita GDP in the region of $\$ 4404$ (39). The breakeven cost per dose-the cost per dose below which the vaccine became cost saving-was $\$ 3.50$ in the societal perspective analysis and less than $\$ 1$ per dose in an analysis that considered health care system costs alone.

\section{Sensitivity analyses}

Sensitivity analysis evaluated the influence of specific inputs on the costeffectiveness of vaccination by varying these inputs across plausible ranges. Holding vaccine cost per dose constant at the PAHO Revolving Fund price of $\$ 53$, the model was most sensitive to estimates of vaccine dose cost, disease costs, and pneumonia-related vaccine 
FIGURE 2. Tornado diagram summarizing sensitivity analyses

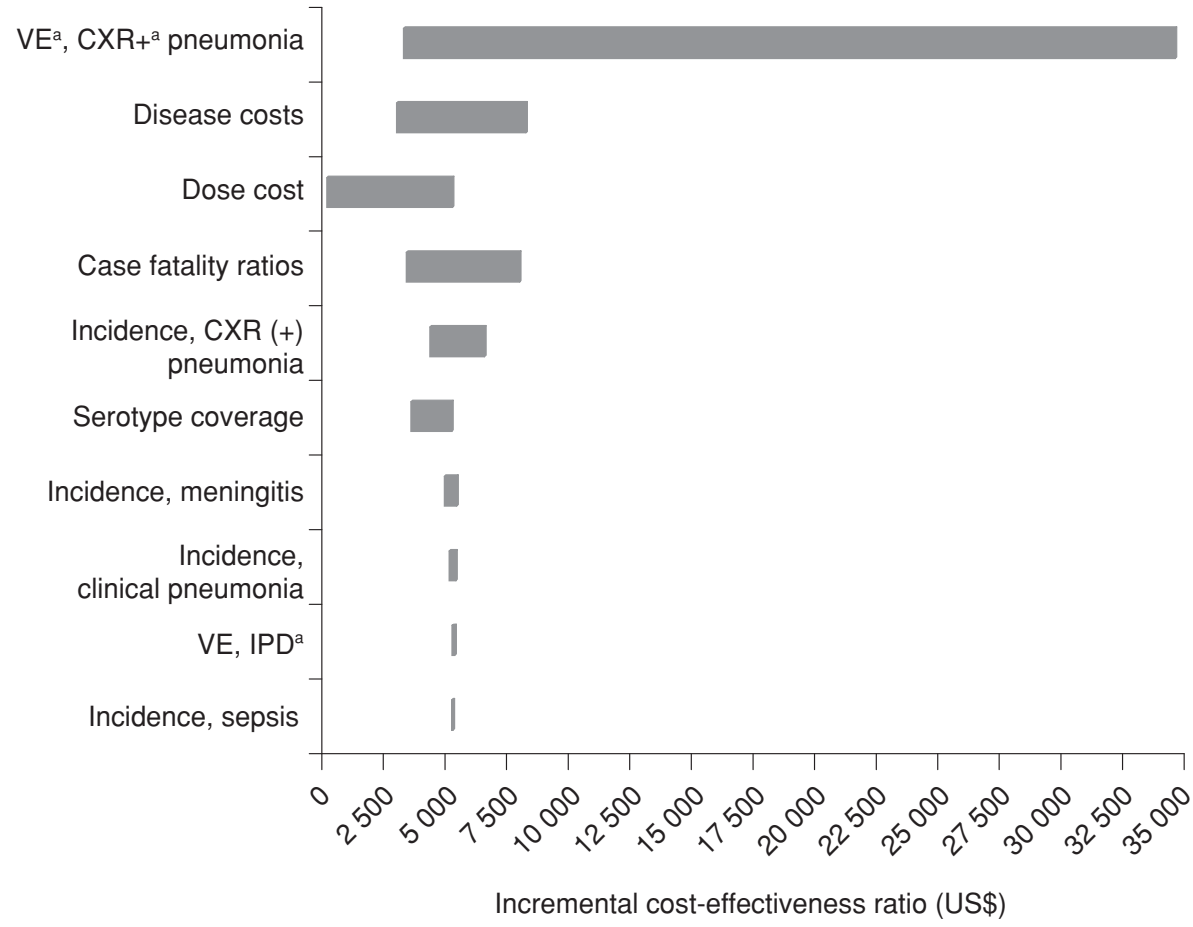

a Termini of bars represent incremental cost-effectiveness ratios at the low and high assumption values given in Table 2. Longer bars represent assumptions to which the model is relatively more sensitive. VE = vaccine efficacy, IPD = invasive pneumococcal disease, $\mathrm{CXR}=$ chest $\mathrm{x}$-ray.

efficacy (Figure 2). As the estimates of vaccine efficacy against clinical pneumonia and chest $\mathrm{x}$-ray-confirmed pneumonia were varied simultaneously, the cost per DALY saved ranged between \$3 269 and \$34 588 per DALY averted.

In sensitivity analysis using the high and low estimates for disease-related direct medical and nonmedical costs, cost per DALY averted ranged from $\$ 2988$ to $\$ 8234$ when vaccine dose cost was held constant at the base case value of $\$ 53$. If serotype coverage were equal to the estimated coverage of a 13-valent conjugated vaccine currently in development, the cost per DALY and per life saved would decrease from $\$ 5252$ and $\$ 178000$ to $\$ 3571$ and $\$ 121000$, respectively. In an analysis in which we considered a four-dose schedule as opposed to a three-dose schedule, the cost-effectiveness ratio was $\$ 7100$ per DALY averted. The model was relatively insensitive to estimates of disease incidence across the plausible ranges considered.

\section{DISCUSSION}

At current vaccination rates, PCV in Latin America and the Caribbean could prevent more than 856000 cases of disease and save approximately 9500 lives annually in children 0 to 5 years old. Furthermore, across a wide range of vaccine costs per dose, pneumococcal vaccine would be a cost-effective purchase in the region, based on WHO standards for evaluating the economic value of health interventions. At dose costs below $\$ 3.50$, the vaccine would be cost saving to the region.

Our analysis incorporated data from a recently completed systematic review of the pneumococcal epidemiologic literature in Latin America and the Caribbean. It integrated empirically collected cost-of-illness data with these epidemiologic estimates to develop the first regional economic model of PCV introduction in Latin America and the Caribbean. It complements other national, regional, and international efforts to develop further understanding of PCV's value. These efforts include PAHO's Pro Vac Initiative, which aims to put streamlined, user-friendly costeffectiveness models in the hands of technical users in national ministries of health. These efforts also include WHO's project to estimate the global burden of pneumococcal disease, with results expected in 2008.

Decisions about the introduction of $\mathrm{PCV}$ in some of these countries are likely be made in the near future. Traditionally, newer, more expensive vaccines such as Haemophilus influenzae type B and hepatitis B have been slow to reach national immunization programs in the region, partly because of their cost (14). However, innovative financing mechanisms, such as advance purchase commitments $(40,41)$ and international financing facilities, are being considered for the purchase and provision of PCV to accelerate its adoption by low-income Global Alliance for Vaccines and Immunizations-eligible countries, six of which are in the Latin American and Caribbean region. However, challenges remain in developing financing mechanisms for vaccine purchase in middle-income Latin American and Caribbean countries, where $>90 \%$ of children in the region are born. This analysis lends weight to the assertion that such investments would prove lifesaving and very cost-effective in most countries in the region.

Our results are in accord with earlier analyses of vaccines for three Latin American countries (Brazil, Chile, and Uruguay) that suggested that pneumococcal vaccination would have costeffectiveness ratios of $\$ 664, \$ 2019$, and \$1 546 per DALY averted, respectively, and the potential to be cost-effective in this region (26).

This study's primary result-that PCV will prevent cases of disease and deaths and will be cost-effective across a range of dose costs-was robust when assumptions were varied in sensitivity analyses. Cost-effectiveness was driven largely by vaccine cost, disease cost, and vaccine efficacy and was less sensitive to other assumptions.

Our analysis was conservative in that it did not account for herd protection, because of the relative paucity of bur- 
den-of-disease estimates for older children and adults. Herd protection is the indirect protection conferred by vaccine on nonvaccinated members of the population through decreased transmission of the organism (42). In the United States, large herd protection effects have been observed in older children, adolescents, and adults, with approximately two cases prevented by herd protection for every case prevented by a vaccine's direct effects (29). In four costeffectiveness analyses of PCV from North America and Europe that have incorporated these U.S. herd protection estimates (43-46), cost-effectiveness ratios have decreased by $31 \%$ to $92 \%$. For example, in a recent U.S. analysis, the estimated cost-effectiveness ratio was $\$ 80000$ per life-year saved before incorporation of herd effects and \$7500 per life-year saved after taking these effects into account (45). Estimates of herd protection effects from countries other than the United States are sparse, but early data suggest that there may be regional differences (47).

Conversely, the analysis did not account for serotype replacement effects. A recent analysis has suggested that serotype replacement may blunt the health benefits conferred by immunization in Alaskan natives (48), but serotype replacement has had a minimal effect in other vaccinated populations $(2,49)$. Only one pharmacoeco- nomic study has explicitly modeled serotype replacement in a sensitivity analysis (44). In that analysis, because nonvaccine serotypes were assumed to cause less severe disease than vaccine serotypes, even $100 \%$ replacement did not eliminate the vaccine's benefits.

The analysis we undertook was regional and did not consider differences among individual Latin American and Caribbean countries. The burden of pneumococcal disease and pneumococcal serotype distribution may vary subregionally and by country. In addition, vaccine administration costs and costs of illness will vary at the country level and by income level. The inputs to our model represented weighted averages of empiric data from countries, extrapolated to represent the region as whole, and hence could not capture these important country-level differences.

The price at which PCV will be offered to Latin American and Caribbean countries in the future is unknown. However, a two-tiered pricing system has long been applied to vaccine prices in international public markets (14). In Latin America and the Caribbean, the PAHO Revolving Fund for Vaccine Procurement purchases vaccines, syringes and needles, and cold chain equipment in bulk for public markets. We ranged the PCV dose cost from $\$ 5$ to $\$ 53$, the current $\mathrm{PAHO}$
Revolving Fund price, and found the vaccine to be cost-effective across most of this range and cost-saving at dose costs below $\$ 3.50$.

Decisions about purchase and provision of pneumococcal vaccine will depend on multiple factors in addition to cost-effectiveness. These factors include affordability, sustainability, programmatic capacity, and competing priorities. However, the public health rationale for introducing pneumococcal vaccination in Latin America and the Caribbean is clear, based on the benefits observed in recent trials, the regional burden of pneumococcal disease, and the economic consequences of vaccine introduction.

Acknowledgments. The authors thank the members of the technical advisory group-Jon Andrus, Brendan Flannery, Orin Levine, Farzana Muhib, Lucia Helena de Oliveira, and Cynthia Whitney-for thoughtful input and discussion. They thank Ana Carvalho, Karen Palacio, and Nate Wolf for administrative and logistic support. This work was presented at the Second Regional Pneumococcal Symposium (Sao Paulo, Brazil, 12-14 December 2006). It was funded in full by the Sabin Vaccine Institute, Washington, D.C. F.d.H. has received a speaker's fee from Wyeth Venezuela. The other authors report no financial conflicts of interest.

\section{REFERENCES}

1. World Health Organization. 2004 global immunization data. Geneva: WHO; 2004. Available from: http://www.who.int/ immunization monitoring/data/Global ImmunizationData.pdf. Accessed 21 December 2006

2. Centers for Disease Control and Prevention. Direct and indirect effects of routine vaccination of children with 7 -valent pneumococcal conjugate vaccine on incidence of invasive pneumococcal disease-United States, 1998-2003. MMWR Morb Mortal Wkly Rep. 2005;54:893-7.

3. Lockhart SP, Hackell JG, Fritzell B. Pneumococcal conjugate vaccines: emerging clinical information and its implications. Expert Rev Vaccines. 2006;5:553-64.

4. Lopez H, Vidal G, Salomon J, Scaglione M, Zitto T. The economic impact of epidemic influenza in Argentina: priorities for intervention. Int J Antimicrob Agents. 2001;17Suppl1:S1-190.

5. Children's Vaccine Initiative and Instituto Nacional de Salud Publica. Evaluación económica de intervenciones en salud: determinación de los costos asociados con algunas enfermedades prevenibles por vacunación en la niñez. Mexico City, Mexico: Children's Vaccine Initiative and Instituto Nacional de Salud Publica; 2001.

6. Arredondo A, Damian T, de Icaza E. Una aproximacion al estudio de costos de servicios de salud en Mexico. Salud Publica Mex. 1995;37:437-45.

7. Arredondo A, Lockett LY, de Icaza E. Cost of diseases in Brazil: breast cancer, enteritis, cardiac valve disease and bronchopneumonia. Rev Saude Publica. 1995; 29:349-54
8. Concha-Barrientos M, Aguilera-Sanhueza $X$, Gonzalez-Weidmaier C. Estudio de costo efectividad: informe final. Technical report. Santiago, Chile: Ministerio de Salud de Chile; 1999.

9. Constenla D. Evaluating the costs of pneumococcal disease in selected Latin American countries. Rev Panam Salud Publica. 2007;22:268-78.

10. Constenla D, Palacio R. Estimación del costo promedio de potenciales componentes de neumococcias en Uruguay. In: Hortal M, Iraola I, Camou T, eds. Avances multidisciplinarios para el control integral de S. pneumoniae-Uruguay-10 años de experiencia. Montevideo, Uruguay: Elsevier; 2004. Pp. 137-44.

11. Constenla D, Valenzuela M. Costo-efectividad de la vacuna pneumococcica conjugada heptavalente en niños bajo 2 años 
de edad [abstract]. Viña del Mar, Chile: Congreso de Infectología; 2006.

12. Alvis N, de la Hoz F, Higuera A, Pastor D, Di Fabio J. Costos económicos de las neumonías en niños menores de 2 años de edad en Colombia. Rev Panam Salud Publica. 2005;17:178-83.

13. Hinman AR. Financing vaccines in the 21st century: recommendations from the national vaccine advisory committee. Am J Prev Med. 2005;29:71-5.

14. Lieu TA, McGuire TG, Hinman AR. Overcoming economic barriers to the optimal use of vaccines. Health Aff (Millwood). 2005;24:666-79.

15. Constenla D, Gomez E, de la Hoz F, O'Loughlin R, Sinha A, Valencia JE, et al. The burden of pneumococcal disease and the cost effectiveness of a pneumococcal vaccine in Latin America and the Caribbean: a review of the evidence and a preliminary economic analysis. Washington, D.C.: Albert B. Sabin Vaccine Institute; 2007. Pp. 1-66.

16. Gold MR, Siegel JE, Russell LB, Weinstein MC. Cost-effectiveness in health and medicine. New York: Oxford University Press; 1996.

17. Drummond MF, O'Brien B, Stoddart GL, Torrance GW. Methods for the economic evaluation of health care programmes. 2nd ed. Oxford: Oxford University Press; 2000.

18. Black SB, Shinefield HR, Ling S, Hansen J, Fireman B, Spring D, et al. Effectiveness of heptavalent pneumococcal conjugate vaccine in children younger than five years of age for prevention of pneumonia. Pediatr Infect Dis J. 2002;21:810-5.

19. Black SB, Shinefeld HR, Fireman B, Lewis E, Ray P, Hansen JR, et al. Efficacy, safety and immunogenicity of heptavalent pneumococcal conjugate vaccine in children. Pediatr Infect Dis J. 2000;19:187-95.

20. Fireman B, Black SB, Shinefield HR, Lee J, Lewis E, Ray P. Impact of the pneumococcal conjugate vaccine on otitis media. Pediatr Infect Dis J. 2003;22:10-6.

21. Pan American Health Organization. Health situation in the Americas: basic indicators. Washington, D.C.: Pan American Health Organization, Health Analysis and Information Unit; 2005.

22. World Health Organization. Life tables for 191 member states. Available from: http://www3.who.int/whosis/life/life tables/life_tables.cfm. Accessed 2 December 2005 .

23. Teele DW, Klein JO, Rosner B, Greater Boston Otitis Media Study Group. Epidemiology of otitis media during the first seven years of life in children in greater Boston: a prospective, cohort study. J Infect Dis. 1989;160:83-94.

24. Valenzuela MT, O'Loughlin R, de la $\mathrm{Hoz}$ Restrepo F, Gomez E, Constenla DO, Sinha A, et al. The burden of pneumococcal disease in Latin America and the Caribbean: a review of the evidence. Rev Panam Salud Publica. In press.

25. Rudan I, Tomaskovic L, Boschi-Pinto C, Campbell H. Global estimate of the inci- dence of clinical pneumonia among children under five years of age. Bull World Health Organ. 2004;82:895-903.

26. Constenla D. Evaluating the cost-effectiveness of a pneumococcal conjugate vaccination program in selected Latin American countries. Rev Panam Salud Publica. 2007;22:268-78.

27. Hansen J, Black $S$, Shinefield $H$, Cherian T, Benson J, Fireman B, et al. Effectiveness of heptavalent pneumococcal conjugate vaccine in children younger than 5 years of age for prevention of pneumonia: updated analysis using World Health Organization standardized interpretation of chest radiographs. Pediatr Infect Dis J. 2006;25:779-81.

28. Lexau CA, Lynfield R, Danila R, Pilishvili T, Facklam R, Farley MM, et al. Changing epidemiology of invasive pneumococcal disease among older adults in the era of pediatric pneumococcal conjugate vaccine. JAMA. 2005;294:2043-51.

29. Reingold A, Hadler J, Farley MM, Harrison LH, Lynfield R, Besser J, et al. Direct and indirect effects of routine vaccination of children with 7-valent pneumococcal conjugate vaccine on incidence of invasive pneumococcal disease-United States, 1998-2003. MMWR Morb Mortal Wkly Rep. 2005;54:893-7.

30. Goldblatt D, Southern J, Ashton L, Richmond $\mathrm{P}$, Burbridge $\mathrm{P}$, Tasevska J, et al. Immunogenicity and boosting after a reduced number of doses of a pneumococcal conjugate vaccine in infants and toddlers. Pediatr Infect Dis J. 2006;25:312-9.

31. Cutts F, Zaman A, Enwere G, Jaffar S, Levine OS, Okoko JB, et al. Efficacy of nine-valent pneumococcal conjugate vaccine against pneumonia and invasive pneumococcal disease in the Gambia: randomised, double-blind, placebo-controlled trial. Lancet. 2005;365:1139-46.

32. Klugman K, Madhi SA, Huebner RE, Kohberger R, Mbelle N, Pierce N. A trial of 9-valent pneumococcal conjugate vaccine in children with and those without HIV infection. N Engl J Med. 2003;349:1341-8.

33. Global Alliance for Vaccines and Immunization. Pneumococcal conjugate vaccine expression of interest letter. Geneva: GIVA; 2007. Available from: http://www. gavialliance.org/support/what/nvs/ index.php. Accessed 8 September 2008.

34. Szklo M, Nieto FJ. Epidemiology: beyond the basics. Gaithersburg, MD: Aspen Publishers; 2000.

35. Constenla D. Evaluating the cost-effectiveness of a pneumococcal conjugate vaccination programme in Latin America [Phd thesis]. Department of Public Health and Policy, Health Services Research Unit. London: London School of Hygiene and Tropical Medicine; 2005. Pp. 53-65.

36. Murray CJL, Lopez AD. The global burden of disease. 1st ed. Vol. I. Geneva: World Health Organization; 1996.

37. Fox-Rushby JA, Hanson K. Calculating and presenting disability-adjusted life years (DALYs) in cost-effectiveness analysis. Health Policy Plan. 2001;16:326-31.
38. World Health Organization. World health report 2002: reducing risks, promoting healthy life. Geneva: WHO; 2002. Pp. $1-230$.

39. World Bank. WDI online. Available from: http://publications.worldbank.org/WDI/. Accessed 2 December 2005

40. Tremonti G. Advanced market commitments for vaccines, a new tool in the fight against disease and poverty: report to the G8 Finance Ministers. 2005. Available from: http://www.innovativefinanceoslo.no/pop.cfm?FuseAction=Doc\&p Action $=$ View\&pDocumentId $=11529$. Accessed 9 September 2008.

41. Berndt ER, Hurvitz JA. Vaccine advancepurchase agreements for low-income countries: practical issues. Health Aff. 2005;24:653-65.

42. Musher DM. Pneumococcal vaccine-direct and indirect ("herd") effects. N Engl J Med. 2006;354:1522-4.

43. McIntosh ED, Conway P, Willingham J, Hollingsworth R, Lloyd A. Pneumococcal pneumonia in the UK-how herd immunity affects the cost-effectiveness of 7-valent pneumococcal conjugate vaccine (PCV). Vaccine. 2005;23:1739-45.

44. Melegaro A, Edmunds WJ. Cost-effectiveness analysis of pneumococcal conjugate vaccination in England and Wales. Vaccine. 2004;22:4203-14.

45. Ray GT, Whitney CG, Fireman $\mathrm{BH}$ Ciuryla V, Black SB. Cost-effectiveness of pneumococcal conjugate vaccine: evidence from the first 5 years of use in the United States incorporating herd effects. Pediatr Infect Dis J. 2006;25:494-501.

46. Wisloff $\mathrm{T}$, Abrahamsen TG, Bergsaker MA, Lovoll O, Moller P, Pederen MK, et al. Cost effectiveness of adding 7-valent pneumococcal conjugate (PCV-7) vaccine to the Norwegian childhood vaccination program. Vaccine. 2006;24:5690-9.

47. Albrich W, Madhi SA, Lafond KE, Klugman KP. Herd immunity after pneumococcal conjugate vaccination [letter]. Lancet. 2007;370:218-9.

48. Singleton RJ, Hennessy TW, Bulkow LR, Hammitt LL, Zulz T, Hurlburt DA, et al. Invasive pneumococcal disease caused by nonvaccine serotypes among Alaska native children with high levels of 7-valent pneumococcal conjugate vaccine coverage. JAMA. 2007;297:1784-92.

49. Hicks LA, Harrison LH, Flannery B, Hadler JL, Schaffner W, Craig AS, et al. Incidence of pneumococcal disease due to non-pneumococcal conjugate vaccine (PCV7) serotypes in the United States during the era of widespread PCV7 vaccination, 1998-2004. J Infect Dis. 2007;196: 1346-54.

Manuscript received on 28 November 2007. Revised version accepted for publication on 23 June 2008 
RESUMEN Objetivo. En América Latina y el Caribe, la vacunación sistemática de niños contra Streptococcus pneumoniae podría requerir inversiones considerables de los gobiernos y organizaciones donantes. Al evaluar estas inversiones se requiere información sobre los posibles beneficios sanitarios, costos y rentabilidad (relación costo-efectividad) de la vacunación. Se presenta un análisis económico de la vacunación infantil antineumocócica en América Latina y el Caribe a partir de la información de la vacuna y de datos demográficos, epidemiológicos y de costos.

Métodos. Se realizó una revisión bibliográfica estructurada previa para llegar a estimados regionales de la incidencia de la enfermedad. Los costos se tomaron de entrevistas a médicos y tarifas públicas. Se construyó un modelo analítico de decisión para comparar la vacunación de los niños de esta región con la vacuna antineumocócica conjugada y la no vacunación, tomando en cuenta solamente el efecto directo de la vacuna en los niños.

Resultados. Se proyectó la vacunación antineumocócica con las tasas de cobertura de la vacuna contra la difteria, el tétanos y la tosferina para prevenir 9500 muertes anuales en menores de 5 años en esta región, o aproximadamente 1 vida salvada por cada 1100 niños vacunados. Las vidas salvadas y los casos prevenidos de sordera, trastornos psicomotores y convulsiones equivalen a evitar anualmente 321000 años de vida ajustados por incapacidad (AVAD). A un precio de la vacuna de US\$ 5,00 a US\$ 53,00 por dosis, el costo por AVAD evitado desde el punto de vista de la sociedad sería de US\$154,00 a US\$ 5252,00 .

Conclusiones. La vacuna antineumocócica conjugada fue altamente rentable hasta un precio de US\$ 40,00 por dosis. La introducción de esta vacuna en América Latina y el Caribe puede reducir la mortalidad infantil con una alta rentabilidad en un amplio espectro de posibles costos.

Palabras clave Streptococcus pneumoniae, vacunas neumocócicas, costos y análisis de costo, árboles de decisión, otitis media, neumonía, sepsis, meningitis, América Latina, región del Caribe.

\section{Avances recientes en inmunización, 2ª . Edición}

Gracias a los esfuerzos de los programas de inmunización en los países de la Región se ha logrado erradicar la poliomielitis y el sarampión; controlar el tétanos neonatal, la difteria y las tos ferina; introducir y aplicar de forma sostenible nuevas vacunas en programas nacionales de vacunación y conseguir niveles altos de cobertura para enfermedades como hepatitis $B$, rubéola, paperas e infecciones por Haemophilus influenzae tipo $B$.

Este progreso ha sido extraordinario, pero no ha tenido una distribución uniforme. Algunos países aún cuentan con segmentos importantes de población que viven en zonas cuya cobertura de vacunación es inferior a 95\%, poniéndolos en riesgo de brotes de sarampión extensos en caso de importaciones del virus del sarampión. Claramente, se debe abordar esta agenda inconclusa.

Los capítulos del libro intentan abordar algunos de los enormes desafíos técnicos y programáticos que ciertos países deben superar para poder completar la agenda inconclusa. El libro está fundamentalmente dirigido a ayudar a los gerentes de inmunización nacionales y a su personal, pero muchos otros profesionales de la salud y otros grupos lo encontrarán útil. Estudiantes de escuelas de salud pública, medicina y enfermería; epidemiólogos y especialistas en control de enfermedades; expertos en vigilancia epidemiológica de las enfermedades prevenibles mediante vacunación; expertos en vacunas; e infectólogos probablemente también se beneficiarán de este libro.

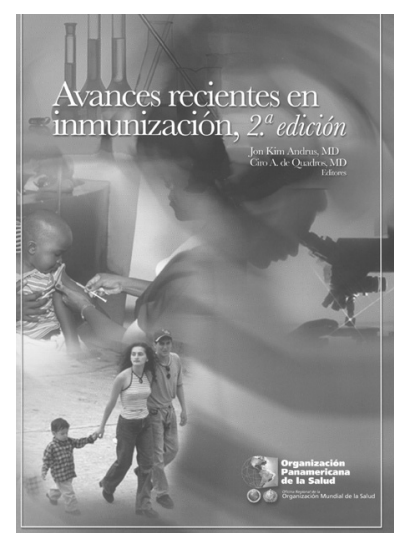

2007, 154 p.,

ISBN: 9275316198

Código: PC 619

Precio: US\$ 18.00 en América Latina y el Caribe/ US\$26.00 en el resto del mundo 